\title{
Social Irresponsibility in Science
}

THE British Society for Social Responsibility in Science is perhaps more than other new organization in great need of that claim on public attention which the Americans call credibility. Everybody agrees, of course, that no harm can be done by a sober examination of some of the questions that sensible people must ask about some of the social problems occasioned by modern science and, more particularly, by modern technology. There is even a need that public attention should be drawn to some of these issues and to the general need for vigilance. In this sense, the British Society for Social Responsibility seemed to have a useful job to do when it began just over two years ago. Its difficulties since then seem to have stemmed largely from the problem of how to provide a commentary on current affairs which is at once lively and balanced.

The society's efforts so far have not been conspicuously successful. What might have been a valuable public discussion on the ethical problems of modern biology (see Nature, 228,$900 ; 1970$ ) seems to have tailed off into discussion of the process of radicalization of science and even some of the familiar problems of Vietnam. It is of course unavoidable that an organization like this should be seen as a vehicle for other causes than those included in the prospectus and in ordinary circumstances many scientists would be willing to forgive the society its errors of judgment and its excesses for the sake of what might be done.

It is therefore a great misfortune that the society should now have chosen to make an ass of itself in public over its relations-and in particular its lack of a formal relationship-with the British Association. At the last annual meeting of the British Association in Durham, members of the society created a stir, sometimes a healthy stir, by speaking up at public meetings, sometimes by interrupting public meetings and by organizing public spectacles of various kinds.

Since then the society has been debating within itself the principles on which its relations with the British Association should be determined and the outcome seems to be the decision not for the time being to cooperate with the association. This view is summarized in the current issue of New Scientist (February 11, 1971) by Mrs Hilary Rose, the new chairman of the society, who protests (quite legitimately) at the composition of the review committee trying to hammer out a role for the association in the years ahead (see Nature, 228, 697; 1970) and then goes on to say that the society

\footnotetext{
"would gladly cooperate with a rejuvenated BA to tackle the problems of the mutual impact of science and society. However, a virtual revolution in BA attitudes and practice is required. Without some concrete evidence that the BA at least realizes the magnitude of the task it faces, BSSRS will feel such cooperation to be futile. It would merely feed complacency, and weaken the impulse to reform."
}

As a part of the same solemn movement of protest, Dr J. R. Ravetz, one of the council of the British Society for Social Responsibility in Science, has taken the deliberate and weighty step of resigning from the association's innocent committee responsible for conducting the affairs of Section X. On the face of things at least, it looks as if diplomatic relations between the two bodies have been severed with all the pomp and dignity appropriate to political rows between the smaller sovereign states.

In all this, it is a great misfortune that the British Society for Social Responsibility in Science has so quickly given in to the temptation to pomposity which has so often in the past been one of the most serious deficiencies of the British Association. The truth is that a body which sets out to be an enlightened pressure group cannot safely afford the luxury of haughtiness. If Mrs Rose means what she says about the society's willingness to cooperate with a rejuvenated British Association, is it not a part of her colleagues' job to help to see that something they would welcome does actually emerge from the deliberations of the review committee, and from the decisions that will eventually be taken about the reorganization of the British Association? If, on the other hand, the British Society for Social Responsibility in Science considers that it would itself be able to perform the contemporary work that the British Association could (and should) be doing, would it not be much more honest to say just that? And would it not then be proper for the society to show that on some occasions at least it can provide the world not merely with the definitions of problems which it considers to be important but also, now and again, with some attempts at constructive solutions? With so much talk and so little work to show, the society has unknowingly as serious a problem on its hands as the British Association.

\section{Postal Strike}

THIS issue of Nature will be the first to be distributed outside North America and parts of the United Kingdom since the beginning of the British postal strike on January 20. Missing copies will be despatched as soon as the strike is over but there will unfortunately be some delay.

Until further notice, and certainly for some days after the strike is over, contributors and subscribers outside Britain should write only to the North American office of Nature, 711 National Press Building, Washington, DC 20004 (telephone 202737 2355). Communications by telex may be sent either to Washington (64280) or to London (262024).

Manuscripts for publication which may eventually be accepted but which are at present embedded in the British postal system will not have been acknowledged as received, and authórs wishing to ensure sáfe delivery should send a duplicate (so marked) to Washington.

Potential contributors may wish to know that the incoming flow of manuscripts for Nature has been so reduced by the strike that the time spent on handling and assessment is much reduced. In the physical sciences in particular, publication is now extremely rapid. 